\title{
A place for 'intercultural' communicative language teaching (iCLT) in New Zealand ESOL classrooms? ${ }^{1}$
}

\author{
Jonathan Newton \\ School of Linguistics and Applied Language Studies \\ Victoria University of Wellington \\ jonathan.newton@vuw.ac.nz
}

\begin{abstract}
Interculturally informed approaches to language teaching and learning are well established in many western educational contexts (e.g. The European Union, North American, Australia) and are in the process of being adopted in languages education in New Zealand schools (The New Zealand Curriculum 2007). However, familiarity with intercultural approaches does not appear to be as widespread within the New Zealand TESOL community.
\end{abstract}

This paper outlines ways in which an intercultural stance has been instantiated in language policy internationally and then discusses a number of pedagogic principles that can assist ESOL teachers to take a more interculturally informed stance towards teaching and learning in their classrooms.

In this paper I review international developments in the area of intercultural language teaching and learning. I argue that TESOL in New Zealand can benefit from greater engagement with these developments. With this in mind, I propose three principles for helping teachers adopt more interculturally oriented classroom practices.

Intercultural language teaching and learning is well established in languages education internationally and is gaining momentum in second language education in New Zealand schools. However, it does not appear to be as well known in the New Zealand ESOL community ${ }^{2}$. To some extent I think that this gap reflects a degree of separation between the languages and TESOL communities in New Zealand. Each community, for instance, has as its own conference (NZALT and CLESOL). ESOL is also distinct from the languages strand in the NZ Curriculum framework, and each community draws on distinct research and scholarship traditions (although with obvious overlaps).

\footnotetext{
1 This paper is informed by research supported by Contract No. 397-2333 awarded to Victoria University from the New Zealand Ministry of Education, However, the opinions expressed in this chapter are those of the authors, and no official endorsement from the Ministry of Education should be inferred.

${ }^{2}$ A notable exception with which I am aware was the course Culture and New Zealand Society taught until recently at UNITEC by Dr Martin Andrew and colleagues. This course focused explicitly and in depth on intercultural dimensions of the interactions and life experiences of ESOL students in the New Zealand community.
} 
Since it is likely that familiarity with the term 'intercultural' is variable, I begin with a discussion of this term. Intercultural language teaching differs from linguistically oriented approaches to language teaching that focus on language with little reference to culture. It also differs from communicative approaches in which culture is an assumed backdrop to communication which may incidentally and haphazardly be bought into focus as the need arises. Rather, intercultural teaching recognizes the intertwined and inseparable nature of language and culture and so treats culture learning as an integral part of all language learning. It is however, most emphatically not just about transmitting information about culture. Instead, it focuses on raising awareness of culture and culture-in-language in the lived experience of the students as well as in the lives of people in the target language community. As such, intercultural teaching is a vehicle for developing in language learners firstly a deeper and more reflective understanding of their own cultural world(s) and identity, and secondly, an understanding of and the skills to accommodate the cultural differences they experience in their lives and interactions. As Gohard-Radenkovic, Lussier, Penz \& Zarate (2004) argue:

...the teaching/learning of modern languages seems to us to be the discipline par excellence for intensifying the openness to other cultures and the contact with otherness in the development of positive cultural representations associated with xenophile attitudes. (p. 53, cited in Rubenfeld, Clement, Lussier, Lebrun \& Auger,, 2006, p.612)

The desired outcome of this approach is learners who can confidently navigate intercultural interactions and relationships, not just because they have achieved a certain level of linguistic or even communicative competence but because they are interculturally competent (Byram, 1997, 2006).

The Finnish scholar, Pauli Kaikkonen (2001) neatly sums up three key characteristics of language teaching which is informed by an intercultural stance. First, it focuses on the inseparable relationship between culture and language, and on the power of language as both a carrier of culture and a tool for constructing our taken-for-granted cultural worlds. Second, it encourages learners to construct their understanding and awareness of culture through observation and experience and reflection. Thirdly, it values learners' subjectivity by involving learners "with their whole personality: as knowing, feeling, thinking and acting individuals" (p. 64).

This stance characterises an intercultural paradigm shift in foreign or second language education in a growing number of education settings over the past 10-20 years. The following section provides a taste of this cultural turn as presented in curriculum and policy documents from Europe, Britain and Australia.

We start with Europe and with what is probably the most influential and widely cited language policy document internationally, The Common European Framework of 
Reference for Languages (Council of Europe, 2001). This document identifies intercultural awareness and intercultural skills as core competencies to be achieved through language education. It expands on intercultural awareness to include:

- openness towards, and interest in, new experiences, other persons, ideas, peoples, societies and cultures;

- willingness to relativise one's own cultural viewpoint and cultural value-system;

- willingness and ability to distance oneself from conventional attitudes to cultural differences. (p.105)

As noted in the framework, "[t]he development of an "intercultural personality" involving both attitudes and awareness is seen by many as an important educational goal in its own right' (p.106).

Similarly, the national languages policy for England as outlined in Languages for all: Languages for life: A strategy for England (Department for Education and Skills, 2002) identifies cultural awareness as an essential educational goal. It states that in the knowledge society of the $21^{\text {st }}$ century, language competence and intercultural understanding are not optional extras, they are an essential part of being a citizen.' (p.5).

In Australia, the National Statement of Languages Education in Australian Schools 2005-2008 (Ministerial Council on Education, Employment, Training and Youth Affairs, 2005) emphasizes the importance of intercultural language learning to the overall education of learners and to the broader community, noting that learning languages:

- $\quad$ enriches our learners intellectually, educationally and culturally;

- $\quad$ enables our learners to communicate across cultures;

- contributes to social cohesiveness through better communication and understanding;

- further develops the existing linguistic and cultural resources in our community;

- contributes to our strategic, economic and international development;

- $\quad$ enhances employment and career prospects for the individual. (p.2)

The document goes on to identify the capacities that intercultural language learning can develop in learners, including the ability to:

- communicate, interact and negotiate within and across languages and cultures;

- understand their own and others' languages, thus extending their range of literacy skills, including skills in English literacy; 
- understand themselves and others, and to understand and use diverse ways of knowing, being and doing;

- further develop their cognitive skills through thinking critically and analytically, solving problems, and making connections in their learning. (p.3)

The New Zealand Curriculum (Ministry of Education, 2007) indicates the future approach to language teaching and learning in New Zealand and takes a similar approach. It introduces the new learning area of Learning Languages to the curriculum by stating that 'learning a new language provides a means of communicating with people from another culture and exploring one's own personal world' (p.24). Under the heading Why study a language?, the document expands on this idea:

By learning an additional language and its related culture(s), students come to appreciate that languages and cultures are systems that are organised and used in particular ways to achieve meaning. Learning a new language extends students' linguistic and cultural understanding and their ability to interact appropriately with other speakers. Interaction in a new language, whether face to face or technologically facilitated, introduces them to new ways of thinking about, questioning, and interpreting the world and their place in it. Through such interaction, students acquire knowledge, skills, and attitudes that equip them for living in a world of diverse peoples, languages, and cultures. As they move between, and respond to, different languages and different cultural practices, they are challenged to consider their own identities and assumptions. (p. 24)

This and the earlier statements from Europe, Britain and Australia all promote a view of language learning as inextricably tied up with learning about culture, and, in the process, learning about the culturally constructed nature of one's own world. The statements also reveal a broad consensus on the role of languages education in fostering cross-cultural understanding and inculcating in learners values associated with both national and global citizenship. In the remainder of this paper I discuss three principles that can guide ESOL teachers to adopt an interculturally informed pedagogy in line with this consensus. These principles, which are well supported in the intercultural literature, are as follows:

1. Engage learners in genuine social interaction.

2. Encourage and develop an exploratory and reflective approach to culture and culture-in-language.

3. Foster explicit comparisons and connections between languages and cultures. $^{3}$

\footnotetext{
${ }^{3}$ These three principles are selected from a larger set of six principles developed in a report to the Ministry of Education and provided in the Appendix to this paper.
} 
The first principle, Engage learners in genuine social interaction, is an obvious starting point for developing intercultural competence. Social interaction forces us to take culture into account in the linguistic and behaviour choices we make, and to consider the effect of these choices on others. One way to improve the quality of social interaction is to embed language learning activities within intercultural communicative events in which learners communicate authentic meanings on topics of value, preferably to someone from the target culture. E-mail and internet based interactive spaces such as Facebook are increasingly popular ways of doing this (e.g. Belz, 2003; Bretag, 2006; Kramsch \& Thorne, 2002; O’Dowd, 2003 and 2007; Ware 2005). There is nothing new about involving learners in genuine communication. But social interaction needs mention here because it underpins an interculturally informed pedagogy just as much as it defines communicative language teaching (CLT). In fact I believe that approaching CLT interculturally greatly enriches communicative methodology. It does so by drawing learners' attention to culturally shaped aspects of communication and behaviour and to their own taken for granted ways of communicating that might otherwise go unnoticed.

At a pre-conference workshop at the CLESOL 2008 conference, Jeremy Harmer showed an interesting example of a communicative event; a video of a multicultural class of young adult ESOL learners in Britain involved in a speed dating scenario. Needless to say, there was plenty of social interaction, though it seems to me that such an activity is culturally risky. Nevertheless it offered intriguing opportunities for learners to reflect on intercultural issues; how they felt taking part in the activity, learners from different cultural backgrounds (European, Asian, Middle-Eastern) comparing their subjective experience of the activity, reflecting on how speed dating might be viewed by other members of their communities, identifying alternative forms of socially sanctioned male-female interactions available in the various cultures represented in the classroom, and so on. Engaging learners in reflecting on these kinds of issues transforms a communicative activity into an overtly intercultural one.

The second principle, Encourage and develop an exploratory and reflective approach to culture and culture-in-language, stands in contrast to the static descriptions of cultural facts often found in traditional approaches to language teaching. Instead of facts about culture, interculturally informed pedagogy explores dynamic aspects of culture in and around everyday language use. Culture pervades everyday uses of language as seen in such things as forms of address used in different circumstances, the marking of formality and interlocutor status, and uses and types of humour and in the behaviour that accompanies language (e.g. gesture, facial expressions, and the culturally shaped daily life rituals in which language is embedded). As Claire Kramsch (1993) has points out, every time we speak we perform a cultural act.

These visible manifestations of culture in language use are underpinned by less easily observed but no less important aspects of culture as captured in the metaphor of the 
cultural iceberg (see Figure 1). A large proportion of culturally shaped knowledge (for example behavioural expectations, and expectations of appropriateness and politeness in verbal and non-verbal behaviour) lies below the surface of culture, and is mostly only subconsciously applied in our everyday interactions.

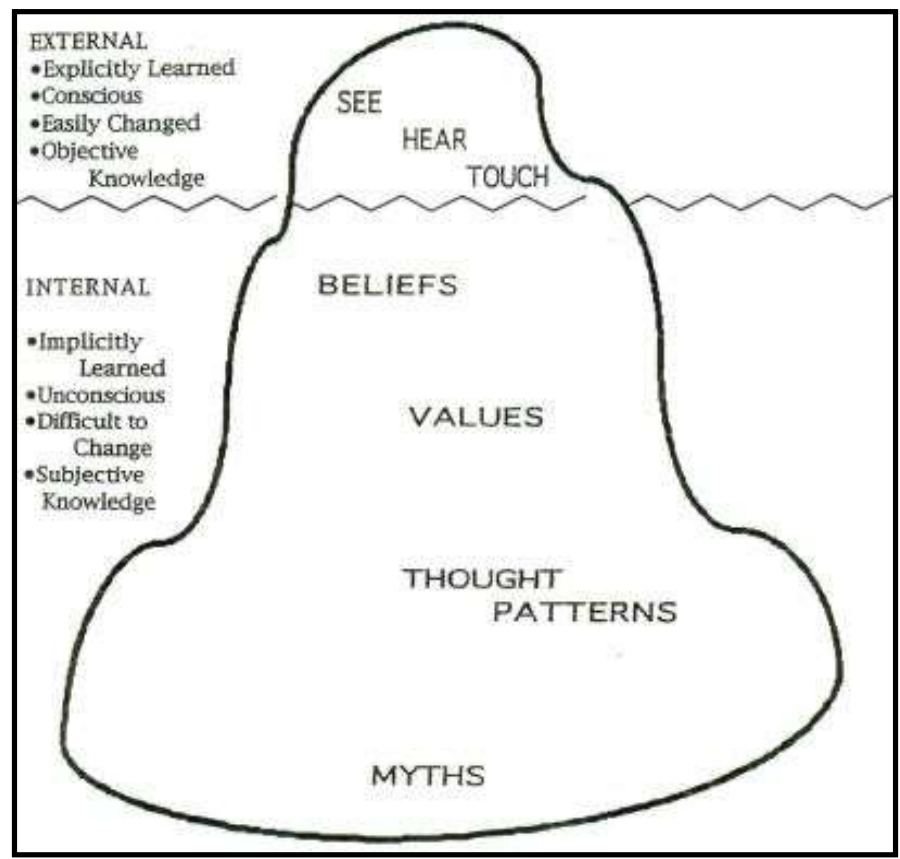

Figure 1: The Cultural Iceberg (Weaver, 1993, sourced www//home.snu.edu/ hculbert/iceberg.htm)

Greeting routines, for example, can be realized in various observable ways including a handshake, raised eyebrows, a kiss, or a nod of the head. However, lying beneath these behaviours are non-observable values, attitudes and expectations to do with status, relationships and social distance, all of which are uniquely structured and perceived within different cultural contexts (Finkbeiner and Koplin, 2002). The iceberg model can also be applied to the language/culture relationship; choice of linguistic form is shaped by 'hidden values, attributions and interpretations of the world' (C. Finkbeiner, personal communication, June 24, 2007). In response to this phenomenon, interculturally informed pedagogy focuses not only on the visible tip of the cultural iceberg but also on the less easily observable, dynamic aspects of culture represented by the large invisible part of the iceberg.

The word 'exploring' in the second principle is synonymous with a constructivist view of education. Exploration allows learners to construct their understandings from first hand experience and reflection, and thereby to engage more deeply in the learning process. In other words, transmission of static culture by teachers is replaced by discovery of dynamic culture by learners. Four simple rules of thumb can help teachers develop an exploratory approach to culture:

1. Emphasize the dynamic and lived experience of culture.

2. Encourage reflective dialogue alongside experience. 
3. Guide students as they interpret their experience of the target culture and language.

4. Provide a metalanguage for discussing intercultural experience, for example: culture, invisible culture, same, different, self, identity, stereotypes, prejudice etc.

These rules of thumb are neatly exemplified in the ABC's activity designed by Claudia Finkbeiner (2006) and presented below. This is a good example of how a learner's first hand intercultural encounters provide the basis for a communicative task that explores cultural differences and similarities and that ensures learners' reflections on experience are central to the task rather than peripheral or incidental.

\section{The ABC's approach to intercultural language learning}

A as in Autobiography

Each learner writes or narrates relevant aspects and/or key events from his or her autobiography.

B as in Biography

Learners interview a partner from a different cultural background (audio or videotaped). The interviewer will then construct a biography describing the key events in that person's life.

$\mathrm{C}$ as in Cross-Cultural Analysis and Appreciation of Differences

Learners study their autobiographies and compare them to the biographies they have written. They write down a list of the similarities and differences.

(Finkbeiner, 2006)

I have presented here only the bare bones of the ABC activity. Obviously each step needs to be carefully scaffolded, language structures and vocabulary supplied, and guidelines given for interacting and comparing. More important for the purposes of this article are the features of interculturally informed pedagogy that this activity so neatly exemplifies:

- the starting point is awareness of self and of one's own culturally shaped reality;

- learners are engaged in genuine social interaction;

- learners construct intercultural understandings through exploration and discovery, rather than through being taught about a culture;

- guided comparison is used to connect cultures;

- culture is treated as dynamic, lived experience rather than static knowledge;

- instruction seeks to develop interculturally tuned communicative competence. 
The third and final of the three principles we will discuss in this paper is Foster explicit comparisons and connections between languages and cultures. Language learning positions learners between languages and between cultures - i.e. in a third space. This can be confusing and disorientating, and can lead to withdrawal into the first cultural place where the learner becomes more resistant to an intercultural understanding of cultural difference. To successfully enter and embrace this third space requires some care on the part of the teacher as s/he guides the learners in exploring cultural similarities and differences (Kramsch, 1993). In resources developed by the Department of Education in Tasmania (N.D. $)^{4}$, the journey to the third space is seen as involving four steps: identify, investigate, reflect and describe. I discuss these steps below and exemplify them with a series of prompt questions from the Tasmanian resource which are designed to guide teachers and learners on the journey of cultural discovery.

The first step, Identify, involves exploring the 'First Place', that is, the learners own cultural world using the following kinds of prompt questions:

- How do these things work in my world?

- How is this situation handled in my culture?

- How would my family and friends react to this situation? (Department of Education, Tasmania, N.D.)

One of the challenges in teaching culture is that knowledge of one's own culture is largely implicit and so not easily available for conscious reflection. We are often unaware of the cultural values which allow us to communicate within our own culture, let alone those that underpin behaviour in another culture with which we come in contact. And yet, as Byram (1997 and 2006) argues, recognising personally held cultural systems is a necessary precondition for identifying these systems in others. For this reason, interculturally-informed language teaching encourages learners to reflect on their own culture as the starting point for intercultural awareness.

The second step, Investigate, involves exploration of the 'Second Place', that is, the cultural worlds of others. The following prompt questions are designed to guide students in their exploration of this second place:

- How do these things work in your world?

- How is this situation handled in your culture?

- How would your family and friends react to this situation?

- How does learning your language help me get to know you better? (Department of Education, Tasmania, N.D.)

\footnotetext{
${ }^{4}$ http://www.education.tas.gov.au/school/educators/resources/lote/cultural/thirdplace
} 
The third step, Reflect, involves a journey to the "Third Space', that is, to a hybrid space in which identity and awareness are no longer constrained by simple dualities, but emerge from deeper understands of self and others, of commonalities and difference; a dynamic space in which cultural givens are open to dialogue and negotiation (Kramsch, 1993). Learners can be guided towards this space with questions such as the following:

- How do similarities/differences between us affect our responses to this situation?

- How does language help us engage and negotiate effectively in this situation?

The fourth and final step, Decide, offers opportunities to explore the 'Third Space' through prompt questions such as:

- How will I decide to behave/respond to this situation?

- What practices will I adopt or reject?

- What attitudes will I consciously cultivate? (Department of Education, Tasmania, N.D.)

As these steps show, comparing cultures is a practical focus for language teaching which allows learners to develop more sophisticated concepts of culture. It helps to undermine notions of the immutability of one's own cultural values and cross-cultural prejudices by "conveying the understanding that one's own as well as the foreign culture are constructs" (Wendt, 2003 p. 97). Thus, gradually, learners 'decentre' from their own culture, viewing it from the perspective of members of other cultures. As Byram (1997) notes, an intercultural approach leads to "the relativization of what seems to the learner to be the natural language of their own identities, and the realization that these are cultural and socially constructed" (p. 22). The end result, as described by Tomlinson \& Matsuhara (2004), is 'a gradually developing inner sense of the equality of cultures, an increased understanding of your own and other people's cultures, and a positive interest in how cultures both connect and differ' (p. 5).

\section{Conclusion}

The research literature in the area of intercultural language teaching and learning is in general agreement that the acquisition of intercultural competence - entering the 'third space' - is not an automatic outcome of second language learning (e.g. Schulz 2007, Sinicrope, Norris \& Watanabe 2007). As Dellit (2005) notes 'ignoring culture does not leave a vacant cultural place which can be filled in later. Rather, it leads to a cultural place which is filled in by uninformed and unanalysed assumptions' (p. 7). To

\footnotetext{
${ }^{5}$ The source material refers to a third 'place' rather than 'space'. I have made the change to 'space' because I prefer the openness implied by the term 'space' and resist any sense of arrival implied by notions of a 'place'. The dynamic nature of identity and of ongoing intercultural experiences make 'arrival' a process not an endpoint.
} 
cultivate intercultural sensitivities in learners requires teachers to adopt an intercultural stance towards culture and language. Culture is no longer ignored or treated incidentally through cultural anecdotes and casual observations or through transmission of cultural information. Instead an intercultural stance produces an integrated and consistent focus on culture as an inseparable part of all language and communication. As Jo Carr (2007) argues, to teach and learn interculturally involves:

an orientation which consciously attends to both language and culture in all second language interactions. Rather than interspersing occasional commentary, triggered by a particular text, we aim now to approach all text and communicative experience in the target language from a cultural as well as a linguistic perspective; to make the experience itself culturally experienced. (p. 26)

The three principles discussed in this paper offer starting points for teachers to integrate this kind of orientation into their classroom practice. Let me stress again that an interculturally informed pedagogy adds value to the teaching and learning goals of linguistic and communicative competence rather than detracting or subtracting from them. By relying on a communicative methodology to achieve the goal of interculturally competent learners, it ultimately enriches this methodology. I therefore consider it timely to consider reframing and revitalizing the familiar term 'communicative language teaching' (CLT) so that it embraces the intercultural. An alternative term intercultural Communicative Language Teaching (iCLT) provides one way of giving the intercultural stance its due weight in the theory and practice of contemporary language teaching.

\section{References}

Belz, J. A. (2003). Linguistic perspectives on the development of intercultural competence in telecollaboration. Language Learning \& Technology, 7(2 ), 68117.

Bretag, T. (2006). Developing 'third space' interculturality in the 'third place' of computer mediated communication. Journal of Computer Mediated

Communication, 11(4). Retrieved from http://jcmc.indiana.edu/vol11/issue4/bretag.html

Byram, M. (1997). Teaching and assessing intercultural communicative competence. Clevedon; Philadelphia Multilingual Matters.

Byram, M. (2006). Language teaching for intercultural citizenship. Keynote address. Paper presented at the NZALT Conference, University of Auckland, 2-5 July 2006

Carr, J. (2007). A critical literacy approach to intercultural language teaching and learning. [Electronic Version]. ILTLP: Self-access module 1. Retrieved February 23, 2007 from www.iltlp.unisa.edu.au/doclibmodules/iltlp_module_self_access01.doc

Council of Europe. (2001). Common European framework of reference for languages. Cambridge: Cambridge University Press. 
Dellit, J. (2005). Getting started with intercultural language learning: A resource for schools. Melbourne: Asian Languages Professional Learning Project, Asia Education Foundation. Retrieved September 2007 from http://www.asiaeducation.edu.au/pdf/developing_intercultural_understanding.

Department for Education and Skills (2002). Languages for all: Languages for life: A strategy for England. Nottingham, DfES Publications.

Department of Education, Tasmania (n.d.) The notion of the third place. Retrieved August 11, 2008 from www.education.tas.gov.au/school/educators/resources/lote/cultural/thirdplace

Finkbeiner, C. (2006). Constructing the third space together: The principles of reciprocity and cooperation. In P. R. Schmidt \& C. Finkbeiner (Eds.), The ABCs of cultural understanding and communication: National and international adaptations (pp. 19-42). Greenwich, CT: Information Age Publishing.

Finkbeiner, C., \& Koplin, C. (2002). A cooperative approach for facilitating intercultural communication [Electronic Version]. Reading online, 6. Retrieved July 3, 2007 from http://www.readingonline.org/newliteracies/finkbeiner/.

Gohard-Radenkovic, A., Lussier, D., Penz, H., \& Zarate, G. (2004). Reference fields and methodologies. In G. Zarate, A. Gohard-Radenkovic, D. Lussier \& H. Penz (Eds.), Cultural mediation and the teaching and learning of languages (pp. 2758). Strasbourg Cedex: Council of Europe Publishing.

Kaikkonen, P. (2001). Intercultural learning through foreign language education. In R. Kohonen, P. Jaatinen, P. Kaikkonen \& J. Lehtovaara (Eds.), Experiential learning in foreign language education (pp. 61-105). Harlow: Longman.

Kramsch, C. (1993). Context and culture in language teaching. Oxford: Oxford University Press.

Kramsch, C., \& Thorne, S. (2001). Foreign language teaching as global communicative practice. In D. Block \& D. Cameron (Eds.), Language learning and teaching in the age of globalization (pp. 83-100). London: Routledge.

Ministerial Council on Education Employment Training and Youth Affairs (2005). National statement of languages education in Australian schools: National plan for languages education in Australian schools, 2005-2008. Hindmarsh, SA: The State of South Australia, Department of Education and Children's Services.

Ministry of Education (2007). The New Zealand Curriculum. Wellington: Ministry of Education.

Newton, J., Yates, E., Shearn, S., \& Nowitzki, W. (2009). Intercultural communicative language teaching (iCLT): implications for effective teaching and learning. Unpublished draft report to the Ministry of Education.

O'Dowd, R. (2003). Understanding the "other side": Intercultural learning in a Spanish-English e-mail exchange [Electronic Version]. Language Learning \& Technology, 7, 118-144. Retrieved 1 April 2007 from http://lit.msu.edu/vol7num2/odowd/.

O'Dowd, R. (2007). Evaluating the outcomes of online intercultural exchange. ELT Journal, 61(2), 144-152.

Rubenfeld, S., Clement, R., Lussier, D., Lebrun, M., \& Auger, R. (2006). Second 
language learning and cultural representations: Beyond competence and identity. Language Learning, 56, 609-631.

Schultz, R. (2007). The challenge of assessing cultural understanding in the context of foreign language instruction. Foreign Language Annals, 40(1), 9-26.

Tomlinson, B., \& Matsuhara, H. (2004). Developing cultural awareness: Integrating culture into a language course. Modern English Teacher, 13(1), 1-7.

Sinicrope, C, J. Norris, \& Y. Watanabe. (2007). Understanding and Assessing Intercultural Competence: A Summary of Theory, Research, and Practice. Technical Report for the Foreign Language Program Evaluation Project. University of Hawai' $i$ at Mānoa (http://wwww2.hawaii.edu/ jnorris/, retrieved June 2007)

Ware, P. (2005). "Missed" communication in online communication: Tensions in a German-American telecollaboration [Electronic Version]. Language, Learning \& Technology, 9, 64-89. Retrieved 31 March 2007 from http://lit.msu.edu/vo19num2/ware/.

Wendt, M. (2003). Context, culture and construction: Research implications of theory formation in foreign language methodology. In M. Byram \& P. Grundy (Eds.), Context and culture in language teaching and learning (pp. 92-105). Clevedon Hall, Clevedon: Multilingual Matters.

\section{Appendix}

Six principles of intercultural communicative language teaching and learning (iCLT):

1. integrates language and culture from the beginning;

2. engages learners in genuine social interaction;

3. encourages and develops an exploratory and reflective approach to culture and culture-in-language;

4. fosters explicit comparisons and connections between languages and cultures;

5. acknowledges and responds appropriately to diverse learners and learning contexts;

6. emphasises intercultural competence rather than native-speaker competence. (Source: Newton et al, 2009) 